\title{
Marinha mercante e construção naval mexicana e brasileira: a comparação de uma trajetória histórico-econômica
}

\author{
The merchant marine and Mexican and Brazilian naval construction: a \\ comparison of a historic-economic trajectory
}

Alcides Goularti Filho

Professor da Universidade do Extremo Sul Catarinense, Criciúma - SC - Brasil

Programa de Pós-Graduação em Desenvolvimento Socioeconômico

Pesquisador do CNPq

http://orcid.org/0000-0002-0808-4486

dalcides@unesc.net

Fecha de recepción: 31 de mayo de 2017

Fecha de aceptación: 24 de julio de 2017

Sugerencia de citación: Goularti Filho, A. (2017). Marinha mercante e construção naval mexicana e brasileira: a comparação de uma trajetória histórico-econômica. tiempo\&economía, 4(2), 113-138, doi: http://dx.doi.org/10.21789/24222704.1224

\section{RESUMO}

O objetivo deste artigo é descrever e analisar a trajetória da marinha mercante e da construção naval Brasileira e Mexicana a partir do final do século xIx até os anos 1970; numa perspectiva da história econômica. O foco principal está concentrado nos aspectos institucionais, produtivo e político, com ênfase no papel do Estado no incentivo ao desenvolvimento do setor de navegação. Além da introdução e das considerações finais, o texto está dividido em três tópicos. O primeiro analisa as diferenças e semelhanças na formação do sistema de transportes do México e do Brasil. O segundo aborda os diferentes rumos seguidos por ambos os países no seu processo de formação do sistema nacional de economia. Por fim, o terceiro analisa 
especificamente a trajetória do setor naval entre 1920 até 1970, destacando o papel do Estado na formulação de políticas de desenvolvimento na marinha mercante e na construção naval.

Palavras-chave: marinha mercante, construção naval, Brasil, México, Economia, História, História econômica

Códigos JEL: N66, N76, N96

\section{ABSTRACT}

The purpose of this article is to describe and analyze the trajectory of the merchant marine and the Brazilian and Mexican naval construction of the late nineteenth century until 1970 from a perspective of economic history. The article focuses on institutional, productive and political aspects, emphasizing the State's role in fostering the development of the shipping industry. First, the article analyzes the differences and similarities in the formation of the transportation system in Mexico and Brazil. Then, it addresses the different paths followed by both countries in their process of establishing the national economy system. To conclude, the history of the post-1920 naval sector until 1970 is specifically analyzed, highlighting the role of the State in the formulation of development policies in the merchant marine and in naval construction.

Keywords: merchant marine, naval construction, Brasil, Mexico, Economy, History, Economic History

JEL Codes: N66, N76, N96 


\section{Diferenças e semelhanças na formação do sistema de transportes}

As duas maiores economias da América Latina pertencem ao México e ao Brasil, que conta com uma população de 202 milhões de habitantes, um PIB de 2,2 trilhões de dólares e uma extensão territorial de 8,5 milhões de quilômetros quadrados. Já o México, por sua vez, conta com uma população de 118 milhões de habitantes, um PIB de 1,2 trilhão de dólares e um território de 1,9 milhão de quilômetros quadrados. Ambos são países com considerável diversidade étnica e cultural, amplos parques industriais, sistema de logística integrado e agricultura moderna, porém sofrem com profundas desigualdades sociais e um sistema político dominado pelas elites conservadoras. A combinação desses elementos resultou na modernização conservadora, a síntese da trajetória dos países latino-americanos, onde lado a lado convivem estruturas modernas, que rapidamente incorporaram os avanços do progresso técnico, com situações de miséria e abandono social que mesmo com os recentes avanços materiais e sociais na sociedade brasileira, geram uma massa de excluídos do mercado de consumo e das políticas públicas.

Como são economias que incorporaram de forma tardia os adventos da primeira e segunda revolução industrial, em ambas podemos identificar trajetórias comuns de setores industriais. México e Brasil, também são países com ampla diversidade geofísica e sociocultural e seguramente podemos encontrar na sua formação histórica muitas diferenças entre setores da economia, uns mais avançados e complexos, outros com estruturas mais simples e reduzida. É o caso da navegação fluvial. Enquanto o Brasil possui um sistema fluvial navegável de aproximadamente $50.000 \mathrm{~km}$ (sobretudo na região Norte), o que permitiu o surgimento de inúmeras companhias de navegação, a escassez de rios navegáveis no México, apenas 2.900 km dificultou a formação de companhias de navegação voltadas para o interior do território. Os maiores rios navegáveis concentram-se na vertente do Pacífico (Balsa, Lerma, Mayo e Yaqui) e são caudalosos apenas ao longo da estreita planície costeira. Outro fator determinante que contribuiu para definir o sistema e a indústria dos transportes foi a diferença no processo de colonização e ocupação do território. Quando o México foi conquistado pelos espanhóis, já havia povos que ocupavam toda a américa intermédia ou mesoamérica desde 1.500 a.C. Os espanhóis chegaram pelo litoral do Golfo do México (Atlântico) e se dirigiram até o centro do continente e conquistaram Tenochtitlán onde, após dizimarem a civilização asteca, fundaram a Cidade do México. Ao longo do processo colonizador, foram fundadas inúmeras vilas que se localizavam, na sua maioria, no grande planalto central e nas serras Madre (Oriental, Ocidental e de Sur), que atualmente são as maiores cidades mexicanas: Cidade do México, Juarez, Guadalajara, Tijuana, Monterrey, Zapopan, Leon, Puebla, Mérida, San Luiz de Potosí e outras. Haviam dois grandes portos no México, o de Veracruz, no Golfo, que se conectava com o Caribe, à costa leste dos Estados Unidos e a Europa; e o porto de Acapulco, que estava voltado para o Pacífico e se ligava à costa oeste dos Estados Unidos, Filipinas e extremo oriente.

No Brasil, os portugueses também chegaram pelo litoral atlântico, e por ali se estabeleceram e fundaram diversas vilas que se transformaram nos maiores centros urbanos do País, como Rio de Janeiro, Salvador, Recife, Belém e Fortaleza. Um pouco mais ao interior foram fundados São Paulo e Curitiba, e com a prospecção de minérios de ouro e pedras preciosas, chegaram até Minas Gerais, antigo "sertão de Goiás e Mato Grosso". Esse mosaico de cidades concentradas no litoral e algumas dispersas no interior com acesso por via fluvial fez do oceano

tiempo\&economía

Vol. 4 N. ${ }^{\circ} 2$ - Julio - Diciembre de 2017 
Atlântico e das bacias hidrográficas as principais vias de comunicação do Brasil até o final do século xIX. As condições geofísicas possibilitaram ao país desenvolver uma marinha mercante voltada para o transporte aquático entre os portos marítimos e fluviais.

Essa diferença entre o México, uma rede urbana mais concentrada no interior com poucos portos, e o Brasil, disperso pelo litoral com a presença de vários portos, foi determinante na formação e consolidação da indústria da construção naval e da marinha mercante após o ano de 1850 e durante todo o século xx.

Analisando especificamente a trajetória da modernização das estruturas de transportes no Brasil e México nos séculos XIx e Xx, podemos identificar que ambos seguiram percursos muito semelhantes com algumas diferenças no processo de condução das políticas de Estado, no período executado e nos resultados esperados. Países periféricos com dimensão continental, como Brasil, México, Argentina, Índia e Rússia, implantaram uma extensa malha ferroviária integrando todo o território, seja para escoar a produção para os portos exportadores, como o caso das ferrovias do complexo cafeeiro paulista, seja para demarcar e ocupar território, como a Transiberiana, na Rússia. A presença de relevo menos acidentado -grandes planícies e planaltos- facilitava e estimulava a construção de ferrovias, pois os custos para construí-las eram baixos, como nos pampas argentinos e no Decão indiano. Regiões montanhosas dificultavam a construção de ferrovias, mas se os lucros fossem mais atrativos do que as dificuldades, nada impedia que os trilhos fossem assentados em grandes altitudes, como no desfiladeiro do cobre no México.

O último quartel do século XIX e das três primeiras décadas do século XX caracterizam-se pela "era ferroviária". O período da ditadura de Porfirio Diaz (1877-1910) foi o momento da grande expansão ferroviária no México. As ferrovias ligavam desde a Península de Yucatán até a fronteira com os Estados Unidos, no sentido Norte-Sul, ou entre os portos de Tampico (Golfo) a Manzanillo (Pacífico). No Brasil, a grande expansão ocorreu durante a última década do Segundo Reinado (1840-1889) e toda a Primeira República (1889-1930) e atendia as diversas regiões exportadoras do País, além de integração pelo interior, com a ligação entre Rio de Janeiro e Rio Grande do Sul. Os subsídios federais e as facilidades concedidas ao capital externo e, em menor proporção, ao nacional, norteavam a política orientada por ambos os países. A despeito do jogo de interesses entre as elites nativas-crioulas, o Estado nacional e o capital externo, Brasil e México modernizaram sua estrutura de transporte terrestre por meio de uma extensa malha ferroviária que atendia as diversas regiões de cada país. Após o ano 1920, para o México, e 1930, para o Brasil, o que aconteceu no sistema ferroviário foi a estatização e a unificação administrativa por meio da Ferrocarriles Nacionales de México (FNM - criado em 1907 e nacionalizado em 1937) e da Rede Ferroviária Federal Sociedade Anônima (RFFSA - fundada em 1957).

As bases produtivas da economia mexicana foram fundadas no final do século xix e início do xx: um amplo sistema ferroviário, portos localizados no Pacífico e no Atlântico (Golfo do México e Caribe) extração de minérios, prospecção de petróleo, agricultura diversificada, rede urbana no interior e uma população aproximada de 15 milhões de habitantes em 1910. Com a modernização do Estado e a incorporação pelas elites dominantes do conceito de soberania nacional, fruto da Revolução Mexicana e da Constituição de 1917, a economia e a sociedade mexicana, sob o governo de Lázaro Cardenas, viu o início da concretização do projeto nacional 
de industrialização. Na mineração, uma grande riqueza mexicana, foram aprovadas novas medidas de regulamentação do setor, colocando os recursos minerais em prol da industrialização nacional. No final do governo Abelardo Luján Rodríguez, em agosto de 1934, foi criada a Comissão do Fomento Minero (CFM), que nas décadas seguintes transformou-se uma grande holding responsável pela paulatina estatização e nacionalização de inúmeras companhias de mineração. O processo culminou em 1961, quando foi aprovada a nova lei de "mexicanização da mineração", que obrigava que todas as empresas que atuavam no setor deveriam ser de, pelo menos, $51 \%$ de propriedade mexicana. Ainda no ano de 1934, foi criada a Nacional Financeira Sociedade Anônima (NAFISA), um banco destinado à financiar projetos de desenvolvimento nacional. Nos seus primeiros anos de operação a NAFISA apenas incorporou alguns bens ao patrimônio nacional, mas sob o governo de Cárdenas ela passou a operar como banco de incentivo. No setor elétrico, já no governo Cárdenas, em 1937, foi criada a Comissão Federal de Eletricidade (CFE), empresa encarregada de regular, produzir, transmitir e distribuir energia elétrica em todo território mexicano. A CEF inaugura suas atividades no ano seguinte com a construção do Sistema Hidroelétrico Miguel Alemán, que abastecia energia para o Estado do México, até a completa estatização do sistema em 1961. Todo sistema ferroviário, que já havia sido subordinada a holding Ferrocarriles Nacionales de México (FNM), criada em 1907, foi estatizado em 1937. Porém, o maior evento político que permitiu a economia mexicana dar saltos qualitativos, foi a criação da Petróleos Mexicanos Sociedade Anônima (PEMEX) e a estatização de toda a produção (prospecção, refino e transporte) em 1938. No ano da estatização do setor petrolífero, o México já era um grande produtor e exportador mundial, e contava com uma rede de 17 refinarias. Outra medida de impacto, tomada pelo governo Manuel Ávila Camacho, foi a criação da Altos Hornos de México SA (AHMSA) 1942, que tornou-se outro ícone da indústria nacional mexicana. A AHMSA somou-se na oferta de aço com outras duas grandes siderúrgicas mexicanas privadas instaladas em Monterrey a Fundidora de Hierro y Acero de Monterrey e a Hojalata y Lámina SA (HYLSA).

No Brasil, o projeto nacional de industrialização teve início com Getúlio Vargas (1930-1945), que afastou do comando da política central as forças oligárquicas de São Paulo que insistiam no aprofundamento do modelo agrário exportador. Além da implementação de reformas sociais e trabalhistas, Vargas acionou a alavanca da industrialização com a criação da Companhia Siderúrgica Nacional (CSN), em 1942, cujas operações iniciaram em 1946. No setor de mineração, em 1942 foi criada a Companhia Vale do Rio Doce (CVRD), que se transformou numa das maiores mineradoras do mundo nas décadas seguintes. No seu segundo governo (19511954), Vargas aproximou-se mais das forças nacionais e populares e criou, em 1953, a Petróleo Brasileiro Sociedade Anônima (Petrobras), que estatizou toda cadeia produtiva do petróleo. No setor elétrico, a partir da bem sucedida experiência da Companhia Hidroelétrica do São Francisco (CHESF) - criada em outubro de 1945, no final do primeiro governo Vargas - em 1954, foi encaminhado para o Congresso Nacional o projeto para a criação da Centrais Elétricas Brasileiras Sociedade Anônima (Eletrobras), sendo aprovado em 1962. E para financiar os projetos estratégicos para o desenvolvimento nacional, foi criada, em 1952, o Banco Nacional de Desenvolvimento Econômico (BNDE), que nas décadas seguintes se transformou na pedra angular do financiamento de longo prazo. 
A Revolução Mexicana e a Constituição de 1917 criaram as bases políticas e institucionais do México industrial e moderno, os governos nacionalistas das décadas de 1930 e 1940, foram os responsáveis pela criação das bases econômicas e produtivas: CFM, NAFISA, CEF, FNM, PEMEX e AHMSA. No Brasil, a Revolução de 1930 descarrilhou a retrógada oligarquia agrária paulista do poder e sob o comando de Vargas foram implementadas as bases da industrialização: CSN, CVRD, Petrobras, BNDE e Eletrobras. Em ambos países, do ponto de vista do projeto de industrialização nacional, as décadas seguintes (1950 e 1960), também foram muito semeIhantes, com o fortalecimento do conceito de empresa nacional, o crescimento das funções do estado entrando cada vez mais no setor produtivo e financeiro, e na proteção do mercado interno. As instituições voltadas para o campo da pesquisa, ciência e tecnologia, também foram se consolidando, formando em sistema nacional de inovação voltado para atender as demandas domésticas, como o fortalecimento das universidades públicas e de agências de fomento à pesquisa.

\section{Rumos diferentes no século xIx: 0 interior e o litoral}

Com relação à indústria da construção naval mexicana, ainda no período colonial, há registro de pequenos estaleiros que se concentravam próximos aos principias portos do Golfo e do Pacífico, que realizavam serviços de reparo para os navios que por ali atracavam. Também eram construídas pequenas embarcações de madeira que atendiam às demandas locais. $A$ maior concentração foi em torno dos portos de Veracruz e Tampico, no Golfo, e Acapulco e Mazanillo, no Pacífico. As embarcações construídas foram incorporadas à frota naval de guerra da coroa espanhola. Ao mesmo tempo a coroa inibia o surgimento de novas indústrias locais para evitar concorrência com os estaleiros da Metrópole. O mesmo ocorria no Brasil, cuja proibição imposta pela coroa portuguesa também afetava a construção naval. No entanto, isso não impedia que fossem realizadas algumas atividades de reparos nos portos coloniais (Hernández, 1965).

Com o movimento da independência realizado pelos dois países, o México em 1821 e o Brasil em 1822, começaram a organizar sua estrutura administrativa e jurídica dando incentivos à formação de diversas atividades econômicas. A autonomia relativa das jovens nações não significou que enveredaram para uma modernização das suas estruturas de transportes. O México continuou até o último quartel do século com uma pequena marinha mercante, que, com a guerra contra a França (1838-1839) e os Estados Unidos (1846-1848), sofreu grandes perdas, desmantelando sua frota naval. Do ponto de vista institucional e jurídico, durante o breve Segundo Reinado de Maximiliano de Habsburgo (1863-1867) foram aprovadas diversas leis que tinham como objetivo formar uma nova marinha mercante com amparo do recém-empossado imperador. Como o reinado foi curto, muitas das leis editadas não tiveram efeitos, porém, ficou claro que o país necessitava entrar com mais força na navegação de cabotagem e de longo curso (Cardenas de la Pena, 1988).

O primeiro surto modernizador da marinha mercante ocorreu durante o período porfiriato, quando houve investimentos na melhoria dos principias portos marítimos, que se adaptaram às novas embarcações a vapor e concedidas subvenções às companhias de navegação. O capital externo teve plena liberdade para se instalar no país e se fez presente nos principais setores 
da economia, como mineração e petróleo, mas também nos transportes, como na rede ferroviária e nas companhias de transporte de carga e longo curso. Ao capital nacional mexicano coube administrar as menores companhias de navegação, atuando na cabotagem regional, enquanto as maiores companhias que faziam o grosso da cabotagem e a navegação de longo curso ficaram a cargo dos estrangeiros, principalmente estadunidenses. Para cobrir a cabotagem nacional, foi apoiada a criação de empresas nacionais. Em 1882, foi fundada a Companhia Mexicana Transatlântica e a Companhia Mexicana Continental; em 1884, a Companhia Mexicana de Navegação; em 1897, a Companhia de Navegação dos Rios Grijalva, Chilapa e Tulija e, em 1901, a Companhia Industrial de Transportes (Morales Damián, 2008).

A Capitania dos Portos, criada em 1870, era o órgão responsável pelos registros e disciplinamento da pesca e navegação. Com a aprovação do Regulamento da Secretaria de Guerra e Marinha em 1880, foi criado o Departamento da Marinha, que passou a gerenciar os assuntos referentes à navegação. Em 1891, foi criada a Secretaria de Comunicações e Obras Públicas, que assumiu a função de ordenar e investir nas vias marítimas e fluviais de comunicação, ficando o Departamento da Marinha apenas com a função de registro das embarcações. Durante o porfiriato, foram abertas as escolas náuticas de Campeche e de Mazatlán e a Escola Naval Militar de Veracruz. Além de darem suporte à marinha de guerra, as escolas também formava profissionais qualificados para a marinha mercante nacional. Em 1895, as capitanias dos portos são suprimidas e suas atribuições delegadas à marinha de guerra.

Após a independência e até o final do Segundo Reinado, foram aprovados seis decretos que direta ou indiretamente influenciavam a marinha mercante mexicana, como o regulamento para aduana, comércio de cabotagem e estrangeiro (1824, 1827, 1837 e 1849), o ato de navegação (1854), o regulamento de supremas patentes para navegação (1857) e o ordenamento das matrículas para o alistamento dos marítimos (1865). No início do porfiriato, foram reorganizadas as aduanas marítimas e terrestres (1887). O primeiro ordenamento jurídico mais consistente surgiu somente com o Código do Comércio, aprovado em 1889, que regulamentava o comércio marítimo (Cardenas de la Pena, 1988).

A trajetória da construção naval brasileira no século xIx também guarda algumas semelhanças com a mexicana. Mas pelo fato do Brasil ser colonizado a partir do litoral, além dos pequenos estaleiros de reparos junto aos portos, a coroa portuguesa criou cinco arsenais da marinha para dar manutenção a sua frota naval e para construir novas embarcações. Os arsenais construídos foram os seguintes: Pará (1761), Rio de Janeiro (1763), Bahia (1770), Pernambuco (1789) e Santos (1820). Os arsenais mais ativos, que inclusive construíram embarcações grandes, foram o da Bahia e o do Rio de Janeiro. Com o advento do Império, os arsenais continuaram exercendo sua função de abastecer a jovem marinha de guerra brasileira, além de prestarem serviços às companhias de navegação. O maior arsenal do Império era o do Rio de Janeiro, que construía embarcações para a frota naval e fazia os reparos junto à movimentação do porto. Em torno do Arsenal do Rio de Janeiro, junto aos bairros da Prainha e da Saúde, surgiu uma série de pequenos e médios estaleiros que realizavam diversos serviços às companhias de navegação. O maior estaleiro privado era o Estaleiro Ponta da Areia (propriedade da Barão de Mauá), fundado em 1846, em Niterói, que se transformou no grande fornecedor da marinha de guerra brasileira. Ao contrário do México, cujas guerras aniquilaram parte da sua frota naval, no Brasil, a Guerra do Paraguai (1864-1870) serviu como estímulo aos estaleiros brasileiros, sobretudo o Ponta da Areia, que construiu vapores e canhoneiras para a marinha de guerra. A 
forte presença do arsenal da marinha no Rio de Janeiro e o aglomerado de pequenos e médios estaleiros e prestadores de serviços marítimos serviram de base para a formação do complexo da indústria naval pesada do século xx (Goularti Filho, 2011).

Além da presença de uma indústria naval considerável no século XIX, também se desenvolveu no Brasil uma marinha mercante nacional que cobria a extensa costa litorânea. Nas primeiras décadas da navegação a vapor em nível mundial, foi fundada no Brasil, em 1837, a Companhia Brasileira de Paquetes a Vapor, que era responsável em cobrir o litoral brasileiro e, em 1871, desdobrou-se em outras duas grandes companhias, a Companhia Brasileira de Navegação e a Companhia Nacional de Navegação. Além das empresas que faziam todo o litoral, havia inúmeras companhias regionais, como a Baiana, Pernambucana, Amazonense, Paraibana e outras. O Brasil chega ao final do século xıx com uma considerável frota mercante e um aglomerado de estaleiros (Goularti Filho, 2011). Um acontecimento relevante na história da navegação brasileira foi a fundação da Companhia de Navegação Lloyd Brasileiro, em 1890, uma empresa estatal de grande porte, que se tornou símbolo da marinha mercante nacional durante o século $x x$.

Como no Brasil a construção naval e a marinha mercante foram mais expressivas do que a mexicana, o conjunto de ordenamento jurídico e de instituições reguladoras e fomentadoras também foram mais atuantes e expressivas. A Capitania dos Portos, com atribuições para disciplinar os portos, pesca e navegação, foi criada em 1845, que substitui a Intendência dos Arsenais da Marinha, que vinha atuando de forma desarticulada desde 1820. Ambos estavam vinculados ao Ministério da Marinha, que se encarregava das atribuições referentes a segurança e disciplinamento da frota. Cabia ao Ministério da Agricultura, Viação e Obras Públicas a gestão das subvenções financeiras, o fomento às companhias de navegação e o controle estatístico do movimento portuário e marítimo, seja de cabotagem ou longo curso. Entre os regimes jurídicos mais relevantes aprovados na segunda metade do século, destacamos o Decreto 632, de 18 de setembro de 1851, que distribuía subvenções financeiras às companhias de navegação, o Decreto n. 3.631, de 27 de março de 1866, que permitiu que as embarcações estrangeiras pudessem também fazer os serviços de cabotagem, Decreto n. 5.585. de 11 de abril de 1874. que regulamentou a marinha mercante, a construção naval e o comércio de cabotagem e, finalmente, o Parágrafo Único do artigo 13 da Constituição de 1891, que definiu que a navegação de cabotagem seria feita apenas por navios nacionais (Goularti Filho, 2010).

\section{Convergindo e reforçando as diferenças no século xx: Estado e industrialização}

Neste tópico será analisada a trajetória do setor naval mexicano e brasileiro dividido em dois períodos. O primeiro, de 1920 a 1945, que discute a formação das bases nacionais dos dois países. O segundo, de 1945 a 1970, que aborda a ampliação e consolidação dessa base nacional. Ambos analisam a constituição do sistema nacional de economia, destacando o papel desempenhado pela política econômica e o capital estatal e privado nacional na trajetória do setor naval. 


\section{a. Formação das bases nacionais (1920-1945)}

O ano de 1910 representou para a sociedade mexicana o início de um processo de mudanças significativas que alterou as estruturas políticas e econômicas do país, a Revolução Mexicana, que começou com a deposição de Porfírio Diaz e avançou com reformas institucionais. Em meio às turbulências políticas, traição das causas sociais e destruição parcial da estrutura produtiva, em 1917 foi aprovada uma nova constituição que definiria os rumos econômicos do país. Talvez pudéssemos classificá-la como uma constituição intervencionista que dava amplos poderes ao Estado para ordenar, fomentar e conduzir a economia nacional. Para o Brasil, o ano de 1910 significou o continuísmo da velha política "café com leite", cujo comando do Estado estava nas mãos da oligarquia paulista e mineira, que do ponto de vista político representavam os atrasos do liberalismo e do agrarianismo. A mudança ocorreria somente em 1930, quando Getúlio Vargas assume o comando da Nação com um projeto nacional e modernizante de industrialização.

Nos anos de 1920, nos governos de Álvaro Obregón (1920-1924) e Plutarco Elías Calles (1924-1928), os conflitos armados foram se dissolvendo, e a política mexicana começou a ensaiar uma trajetória de normalidade institucional. As eleições presidenciais foram respeitadas e as instituições políticas (partidos, sindicatos e federações) passam a ter mais densidade orgânica na sociedade. O movimento que nasceu com o espírito revolucionário e popular transformou-se em acomodações institucionais para uma elite pseudo reformista. Do ponto de vista do crescimento econômico, os anos de 1920 foram um período de retomada de alguns investimentos, sobretudo com a reconstrução do sistema ferroviário, que havia sido parcialmente destruído durante os conflitos armados, além de algumas melhorias nos portos exportadores. Na mineração de prata houve breves momentos de queda da produção, que rapidamente se recuperou a partir de 1920. A extração de petróleo, que estava se constituindo com a nova economia mexicana nos anos de 1910 e 1920, praticamente passou ilesa, com uma produção crescente até 1925 (Ayala Espino, 2003; Ficker, 2013). Na verdade, o rumo da economia mexicana nas próximas décadas, em boa medida, estará condicionado ao bom desempenho do setor petrolífero, que diretamente influenciará a marinha mercante nacional.

A pauta de exportação mexicana até os anos 1920 era constituída principalmente por petróleo, destinado aos Estados Unidos, e minerais (como ouro, prata, cobre, zinco e chumbo), que somavam $68,0 \%$ do valor total exportado em 1929. Sisal, café, látex, grão-de-bico, carne e couro também ocupavam certa importância na pauta. Sobre as importações, cerca de 90,0\% era de manufaturados, sendo que 27,0\%, entre 1925 e 1929, foram de bens de capital. Os Estados Unidos eram o principal destino $(61,0 \%)$ e também principal partida $(69,0 \%)$ das trocas internacionais (Tello, 2008).

Gestado nos governos Calles e Obregón, o nacionalismo mexicano emergiu com força pelas mãos de Lazaro Cárdenas (1934-1940), quando foram fundadas as bases da economia nacional com caráter mais autônomo. Amparado na Constituição de 1917, que dava mais poderes ao Executivo federal para intervir na economia e no setor produtivo, Cárdenas, em 18 de março de 1938, expropriou e nacionalizou o setor petrolífero e transferiu seus ativos para a estatal recém-criada Pemex (Petróleos Mexicanos Sociedade Anônima). A produção de petróleo, que teve seu destino modificado para atender o mercado interno, passando do nível de 60,0\% produção exportada para apenas 14,0\% 20 anos após a desapropriação, teve um incremento

tiempo\&economía

Vol. 4 N. ${ }^{\circ} 2$ - Julio - Diciembre de 2017 
de 46,8 milhões de barris em 1937 para 56,2 milhões em 1947, mesmo com a queda sentida pelo boicote internacional sofrido pela Pemex nos anos após a desapropriação (Pemex, 1977). A Pemex ainda seria fundamental no desenvolvendo do refino de petróleo, na indústria petroquímica e na produção de gás. O nacionalismo de Cárdenas também chegou ao setor ferroviário, com a centralização das atividades ferroviárias na FNM e na constituição de uma frota petroleira nacional para atender às demandas da Pemex. Também se destacou o plano de desenvolvimento do setor elétrico, que por meio da Comissão Federal de Eletricidade, criada em 1937, multiplicou a produção e a distribuição de energia para toda a economia, permitindo a escalada da produção industrial e surto de modernização vivido no país após 1940. A produção de energia elétrica passou de 1,529 milhão de kWh em 1933 para 2,529 milhões de kWh em 1940 e para 3,069 milhões de kWh em 1950 (Ayala Espino, 2003).

Em 1917, estimulada pelas novas mudanças constitucionais, houve uma reforma administrativa que repassou a direção da marinha mercante da Secretaria de Guerra e Marinha para a Secretaria de Comunicação e Obras Públicas, ou seja, a partir desse momento, a marinha mercante passa a ser conduzida pelo Executivo federal como uma atividade econômica estratégica. Em 1939, foi aprovada a Lei das Secretarias e Departamentos, criando o Departamento da Marinha Mercante e a Secretaria da Marinha. E para fomentar o setor de navegação comercial, em 1947, foi constituída a Comissão da Marinha Mercante Mexicana, órgão vinculado à Secretaria de Comunicações e Obras Públicas, que ficou encarregada de definir os marcos legais, institucionais e financeiros do setor naval.

Nos anos 1920 e 1940, foram registradas as seguintes companhias de navegação mexicana: Compañia Naviera de los Estados de México (1920), Sociedad Cooperativa Mixta Transporte Maritimos y Vias Fluviales (1935) e a Compañia Naviera de Servicios Maritimos Mexicanos (1949). São companhias que nascem sob a proteção da Constituição de 1917, que dava privilégios e proteção à navegação nacional. Com o aumento do fluxo mercantil, sobretudo com as exportações de petróleo, necessariamente o Estado teve que realizar obras no sistema portuário, que já estava descentralizado. No Golfo foram modernizados os portos de Veracruz, Progresso, Tuxpan e Tampico; no Pacífico, os portos de Acapulco, Manzanillo e Mazatlán. Contudo, o acontecimento mais significativo no setor de navegação foi a criação da frota petroleira nacional vinculada à Pemex (Solís e González Sotomayor, 2004; Jáuregui, 2004).

Com relação à construção naval, havia no México, junto aos principais portos, pequenos estaleiros que faziam pequenas embarcações, sobretudo para pesca, e reparos. Também eram atendidas algumas encomendas da marinha de guerra. A base da construção ainda era a madeira, com pouca introdução do ferro e de equipamentos mecânicos e eletrônicos. Esse foi o cenário da construção naval mexicana até o final dos anos 1960, que pouco avançou, mesmo com a indústria de aço já instalada, com a presença de inúmeras companhias de navegação e da Pemex.

Junto ao tradicional porto de Veracruz, onde havia pequenos estaleiros que faziam reparos em embarcações pesqueiras, em 1929, o Comodoro Ignácio García Jurado construiu, próximo à fortaleza de San Juan de Ulúa, um dique seco de 50 metros de comprimento, nove de largura e 2,7 de calado. O objetivo era atender as encomendas da marinha de guerra, que demonstrava interesse em fazer suas aquisições nos estaleiros mexicanos. Foram encomendadas cinco embarcações do tipo guarda costeira. O dique encerrou suas atividades em 1935. Nesse 
mesmo ano, Lázaro Cárdenas levou adiante a primeira tentativa de implantar uma indústria naval pesada no México, quando contratou a construção de dez navios do tipo guarda costeira, quatro canhoneiras e dois navios para transporte de tropas. No contrato realizado com estaleiros espanhóis, estava prevista a transferência de tecnologia por meio da construção conjunta com estaleiros mexicanos. Para tanto, a Secretaria da Marinha fundou um estaleiro em Veracruz e outro em Guaymas e enviou oficiais para cursarem a carreira de engenharia naval na Espanha. Contudo, os planos foram abortados em função da Guerra Civil Espanhola (Escanero Muñoz, 1950, Hernandez, 1965; Rodríguez Ledesma, 1977).

Em 1942, a Secretaria da Marinha encampou os estaleiros que estavam sob a administração da FNM, localizados em Tampicos, Coatzacoalcos e Salina Cruz, que executavam reparos navais e construção de pequenas embarcações pesqueiras. Os mesmos foram convertidos em estaleiros para construção de embarcações da armada nacional. Posteriormente, a Marinha encampou outros pequenos estaleiros localizados em Guaymas, um dique seco em Veracruz e outro pequeno trapiche em Acapulco, formando a Direccion General de Construcciones Navales (Secretaria da Marina, 2012).

Em 1942, impulsionado pela Secretaria da Marinha, foi construído um novo dique (Número 2), junto ao pátio de San Juan de Ulúa com 157 metros de comprimento, 19 de largura e 4,8 de calado. Mais tarde, 1961, toda estrutura foi encampada, formando o Astilleros de Veracruz SA (AVSA), uma empresa estatal de propriedade da Financeira Nacional (Escanero Muñoz, 1950; Instituto para la Integración de América Latina, 1971).

Quando o setor petrolífero foi estatizado em 1938, também foi incorporada ao patrimônio público a frota petroleira que trafegava nos portos mexicanos, como a Naviera San Cristóbal, Naviera San Ricardo e Mexicana de Vapores de San Antonio. No momento da estatização foi incorporado apenas um navio-tanque de grande porte de 6.438 TPB, mas em compensação foram 136 embarcações de pequeno e médio porte que somavam 28.271 TPB. Com a assinatura da declaração de guerra ao Eixo, foram expropriados navios alemães e incorporados à frota da Pemex, que passou de quatro navios-tanques em 1940 para 11 em 1942. Em maio de 1942, os alemães torpedeiam o navio tanque petroleiro mexicano PotrerodelLlano, reafirmando ainda mais o posicionamento do México de aliado dos Estados Unidos. O estreitamento das relações diplomáticas com os Estados Unidos durante a Segunda Guerra acabou por propiciar um aumento das inversões estadunidenses no México, o que não aconteceu durante o governo de Lázaro Cárdenas (Ayala Espino, 2003)

Com os adventos da República no Brasil após 1889, podemos destacar três ações que fortaleceram a marinha mercante brasileira. A primeira foi a criação da Companhia de Navegação Lloyd Brasileiro, em 1890, uma companhia estatal de navegação, que se tornou a âncora do setor por quase 100 anos. A segunda foi o fortalecimento da Companhia Nacional de Navegação Costeira, fundada em 1891, e da Companhia Comércio e Navegação, fundada em 1905 (Burlamaqui, 1918). Incluindo o Lloyd Brasileiro, essas três grandes companhias praticamente dominaram a navegação de cabotagem no Brasil até os anos de 1940. E por último, destacamos a criação da Inspetoria Federal de Navegação (IFN), em 1907, que assumiu as funções da Capitania dos Portos em definir e coordenar as políticas para a marinha mercante brasileira (Ferreira Netto, 1974). 
Nos anos de 1920, a economia brasileira passou por uma diversificação produtiva com o surgimento de setores industriais mais complexos e dinâmicos como cimento, ferro, aço, metal mecânico, papel e celulose, produtos de borracha, químicos e frigoríficos, o que significava mais importações (Suzigan, 2000). Ao mesmo tempo, houve novos surtos na produção de café e decadência na produção de borracha. Esse movimento rebatia nos portos e na navegação, via exportações ou importações, que exigia uma maior atuação das companhias de navegação para atender às demandas nacionais que estavam num rápido processo de integração comercial.

O novo padrão de acumulação, que emergiu após a Revolução de 1930, pautado na industrialização, desenhou um novo arranjo para o sistema de transporte no Brasil. No período compreendido entre a criação da Comissão da Marinha Mercante (CMM), em 1941, à criação do Fundo da Marinha Mercante (FMM), em 1958, paralelo à industrialização restringida, assistimos a três movimentos no setor de navegação: o afastamento do Ministério da Marinha do setor, a deterioração da frota mercante e a instrumentalização política do setor, que culminou com a unificação dos objetivos da marinha mercante com o da construção naval. Amparado pelo novo regime jurídico aprovado em 1939, o Decreto 3.100, de 7 de março de 1941, após recomendações do Conselho Federal de Comércio Externo, criou a CMM, uma autarquia com autonomia administrativa e financeira. Competia à CMM definir as políticas de orientação, organização e financiamento para navegação brasileira.

Com o fim da Segunda Guerra e a retomada do fluxo comercial nos oceanos, a situação se normalizou. A herança para a marinha mercante brasileira foi uma frota envelhecida cuja manutenção ficou comprometida devido à impossibilidade de importar peças de reposição. $\mathrm{Na}$ segunda metade da década de 1940, houve uma renovação na frota do Lloyd Brasileiro, com a compra de 36 navios - 20 cargueiros para longo curso e 16 de cabotagem (Brasil, 1949).

\section{b. Ampliação e consolidação das bases nacionais (1945-1970)}

Após a Segunda Guerra Mundial as principais economias da Europa, os Estados Unidos e o Japão, viveram um período de longo crescimento, estabilidade financeira e ganhos sociais. Essa prosperidade estava fundada, em larga medida, num consenso arquitetado pela regulação política e por mecanismos de intervenção estatal. Na periferia capitalista, também podemos afirmar que houve um período de prosperidade econômica, porém os ganhos sociais foram parcos em comparação aos benefícios concedidos ao capital privado. As três principais economias da América Latina, Brasil, México e Argentina, combinaram ao longo das três décadas após 1945, nacionalismo econômico, industrialização, ampliação do mercado interno e mobilidade social. Cada país fez a combinação de acordo com a sua tradição política e econômica, no entanto, podemos afirmar que os três países seguiram concomitantemente uma trajetória semelhante de industrialização. Brasil e Argentina tiveram rupturas institucionais com golpes militares seguido de ditaduras, o México manteve a alternância do poder sem mudar a hegemonia política. O PRI, herdeiro da Revolução Mexicana, manteve-se no poder durante esse longo período criando, ora políticas mais reformistas sociais, ora apenas industrializantes, porém sempre intervencionistas. O Estado mexicano ampliou cada vez mais a participação na vida social mexicana, atuando diretamente em diversas esferas, promovendo cultura, ampliando setores econômicos, fazendo reforma agrária e tornando cada vez mais complexa a 
vida material. O resultado foi o aumento na renda nacional com melhoria nos índices de distribuição da renda e da terra.

Nesse período a participação do estado nas mais diversas atividades econômicas se ampliou sem precedentes, incluindo na operação do sistema portuário e na construção naval. Esse aumento da presença do Estado foi sentido diretamente a partir de 1963, quando foi aprovada a Lei de Navegação e Comércio Marítimo, que substituiu o antigo Código de Comércio de 1889. A nova lei regulamentou o setor e criou o Registro Público Marítimo Nacional, delegando à Secretaria de Marina as responsabilidades pelas concessões de obras, serviços, operação das companhias, dos estaleiros e registros das propriedades dos navios (Rosales Méndez, 2001).

Em 1958 foi apresentado o programa conhecido como Marcha al Mar (Programa de Progresso Marítimo), que tinha como objetivo estimular a não interiorização do país, deslocando populações do altiplano em direção aos dois litorais, integrar a rede portuária nacional com a construção de novos portos (em destaque o Lázaro Cárdenas, um dos maiores portos na atualidade), melhorar a comunicação entre os portos e as principias cidades, fomentar a marinha mercante e construir novos estaleiros (Solís e González Sotomayor, 2004). No mesmo ano de lançamento do Plano foi fundada a Transportación Marítima Mexicana S.A. (TMM), uma empresa estatal de navegação de cabotagem e longo curso, que nasce financiada pela Banco de México e Nacional Financeira SA. A TMM teria a função de cobrir as rotas do Golfo e do Atlântico e começa operando com apenas uma embarcação de 3.945 TPB, mas segue uma trajetória constante de crescimento, chegando em 1970 a uma frota de 14 navios e um total de 120.065 TPB. Para auxiliar nas rotas do Pacífico, tendo a TMM com holding, em seguida foram fundadas a Compañia Marítima Mexicana, a Transporte Maritimo Anahuac e a Servicios Marítimos de Mexicanos. As duas primeiras operavam apenas com um cargueiro cada, já a última tinha somente embarcações de pequeno porte que fazia o transporte de cabotagem. O objetivo seria ampliar a participação nacional no comércio marítimo mexicano e serviam, além da Pemex, como âncoras para a indústria naval pesada que deveria ser implantada no país com apoio estatal. Outra inserção estatal na matinha mercante foi a entrada da Caminos y Puentes Federales de Ingresos y Servicios Conexos, estatal mexicana responsável pelo sistema rodoviário, que operava com duas pequenas embarcações (Morales Damián, 2008; Instituto de Estudios de la Marina Mercante Iberoamericana, 1972).

Também foi estimulada a formação de companhias privadas, que passaram a operar tanto no Atlântico como no Pacífico, como a Flota Mercante Nacional, Navieros Unidos Mexicanos, Naviera Baja Califórnia, Navieira Ruff, Salinas de Pacífico e Navieira de Pacífico. Todas citadas anteriormente eram empresas de pequeno porte que operavam apenas com um navio de médio porte (Instituto de Estudios de la Marina Mercante Iberoamericana, 1972).

Na Tabela 1 podemos acompanhar a trajetória da frota mercante de dois maiores armadores estatais do México, a TMM e a PEMEX. A TMM iniciou suas atividades em 1958 operando com apenas duas embarcações de 14.146 TPB, no entanto, em apenas 8 anos, já somavam 15 navios num total de 78.610 TPB. Na década de 1960, a PEMEX também ampliou consideravelmente sua frota, passando de 117.624 TPB em 1960 para 339.029 TPB no final da década.

tiempo\&economía 
Tabela 1: Trajetória da frota mercante da PEMEX e da TMM 1945-1970

\begin{tabular}{|c|c|c|c|c|}
\hline \multirow{2}{*}{ Ano } & \multicolumn{2}{|c|}{ PEMEX } & \multicolumn{2}{|c|}{ TMM } \\
\hline & TPB & Navios & TPB & Navios \\
\hline 1945 & 66.625 & 9 & & \\
\hline 1946 & 66.625 & 9 & & \\
\hline 1947 & 66.625 & 9 & & \\
\hline 1948 & 66.625 & 9 & & \\
\hline 1949 & 77.378 & 10 & & \\
\hline 1950 & 113.580 & 14 & & \\
\hline 1951 & 113.580 & 13 & & \\
\hline 1952 & 113.580 & 13 & & \\
\hline 1953 & 124.530 & 14 & & \\
\hline 1954 & 136.768 & 15 & & \\
\hline 1955 & 127.366 & 14 & & \\
\hline 1956 & 127.366 & 14 & & \\
\hline 1957 & 117.624 & 13 & & \\
\hline 1958 & 117.624 & 14 & 14.146 & 2 \\
\hline 1959 & 123.196 & 15 & 10.201 & 1 \\
\hline 1960 & 117.624 & 14 & 14.251 & 2 \\
\hline 1961 & 117.624 & 14 & 28.815 & 6 \\
\hline 1962 & 117.624 & 14 & 28.815 & 6 \\
\hline 1963 & 165.906 & 16 & 49.859 & 9 \\
\hline 1964 & 182.187 & 15 & 56.599 & 11 \\
\hline 1965 & 214.747 & 16 & 70.084 & 13 \\
\hline 1966 & 206.452 & 14 & 78.610 & 15 \\
\hline 1967 & 348.818 & 23 & 69.780 & 13 \\
\hline 1968 & 378.177 & 23 & 95.643 & 14 \\
\hline 1969 & 339.029 & 20 & 91.593 & 13 \\
\hline 1970 & 322.748 & 19 & 120.065 & 14 \\
\hline
\end{tabular}

Fonte: Fundación Histarmar, 2016 (http://www.histarmar.com.ar/)

Comparando com o Brasil, que operava com o Lloyd Brasileiro, desde 1890, e com a Navegação Costeira (estatizada em 1941), duas grandes companhias estatais de navegação, o México entrou tardiamente na constituição de uma frota nacional, somente em 1958. Contudo, o México se antecipou na formação da sua frota petroleira, que nasce com a Pemex, em 1938; em compensação o Brasil começou com a fundação da Frota Nacional de Petroleiros (Fronape) em 1950.

Nos anos de 1950 e 1960, houve um avanço considerável das atividades da Pemex, quando o volume de produção passou de 72.422 mil barris em 1950, para 99.049 mil em 1960 e 
156.586 mil em 1970 (Tabela 2). Esse aumento da produção revela o quanto se alterou a estrutura produtiva no parque industrial mexicano. Além das sete refinarias expropriadas em 1938 (num total de 16 refinarias privadas existentes no país, e todas de capital estrangeiro), em 1946 entrou em operação a Refinaria 18 de março; em 1950, as refinarias Antonio M. Amor e Reynosa, além de ser ampliada a Refinaria Mata Redonda. Em 1955, foi inaugurada a Refinaria Lázaro Cárdenas, a mais moderna na época, com capacidade para o refino de 50 mil barris diários, além de ser inaugurada uma planta de lubrificantes em Salamanca. Nos anos seguintes, amparadas pela Lei do Petróleo de 1958, as diversas refinarias foram ampliadas e passaram a atuar na produção de outros derivados do petróleo. Em 1961, foi inaugurado o gasoduto entre a Cidade do México e Salamanca com 1.889 quilômetros. E no final dos anos de 1960, foram descobertas novas reservas em Tampico, Reynosa, Poza Rica, Chiapas e Tabasco, elevando a produção em 140\% em apenas 10 anos. Na frota petroleira, não houve uma grande ampliação, passando de 17 navios em 1950 para 22 em 1970, porém as novas embarcações adquiridas no exterior eram todas de grande porte, o que permitiu ampliar de 106.164 TPB em 1950 para 227.956 TPB em 1970 (Pemex, 1977).

Tabela 2: Produção anual de petróleo bruto México e Brasil (mil barris) 1945-1970

\begin{tabular}{cccccc}
\hline Ano & Pemex & Petrobras & Ano & Pemex & Petrobras \\
\hline 1945 & 43.543 & 75 & 1958 & 93.533 & 18.926 \\
1946 & 49.240 & 63 & 1959 & 96.393 & 23.593 \\
1947 & 56.298 & 94 & 1960 & 99.049 & 29.612 \\
1948 & 58.520 & 138 & 1961 & 106.784 & 34.808 \\
1949 & 60.902 & 107 & 1962 & 111.849 & 33.418 \\
1950 & 72.422 & 327 & 1963 & 114.867 & 35.726 \\
1951 & 77.308 & 692 & 1964 & 115.576 & 33.311 \\
1952 & 77.278 & 748 & 1965 & 117.959 & 34.342 \\
1953 & 72.433 & 918 & 1966 & 121.149 & 42.450 \\
1954 & 83.651 & 994 & 1967 & 133.043 & 53.520 \\
1955 & 89.395 & 2.019 & 1968 & 142.360 & 58.785 \\
1956 & 90.660 & 4.057 & 1969 & 149.860 & 63.043 \\
1957 & 88.266 & 10.108 & 1970 & 156.586 & 59.967 \\
\hline
\end{tabular}

Fonte: Pemex, 1988; Petrobras 1970

Apesar dos esforços do governo federal em formar um parque industrial naval, todos os estaleiros mexicanos até os anos 1960 continuariam construindo apenas pequenas e médias embarcações, em larga medida destinadas à atividade de pesca. No entanto, era possível fazer reparo de embarcações maiores. A Pemex e a TMM faziam aquisições no exterior, mas reparavam seus navios em estaleiros mexicanos (Tabelas 3 e 4). Inclusive a Pemex tinha a sua própria oficina de reparo em Salina Cruz. 
128 Marinha mercante e construção naval mexicana e brasileira: a comparação de uma trajetória histórico-econômica, doi: http://dx.doi.org/10.21789/24222704.1224

Tabela 3: Aquisições realizadas pela TMM em estaleiros no exterior

\begin{tabular}{ccccc}
\hline Ano de construção & Nome do barco & Tipo & TPB & País de construção \\
\hline 1945 & Aguascalientes & Cargueiro Ultramar & 5.900 & Estados Unidos \\
1945 & Tabasco & Cargueiro Ultramar & 6.000 & Estados Unidos \\
1945 & Tlaxcala & Cargueiro Ultramar & 5.666 & Estados Unidos \\
1954 & Campeche & Cargueiro Ultramar & 3.700 & Suécia \\
1954 & Jalapa & Cargueiro Ultramar & 3.700 & Suécia \\
1956 & Mérida & Cargueiro Ultramar & 5.270 & Dinamarca \\
1964 & El Mexicano & Cargueiro Ultramar & 13.120 & Brasil \\
1964 & Puebla & Cargueiro Ultramar & 13.179 & Brasil \\
1965 & Chihuahua & Cargueiro Ultramar & 3.040 & Brasil \\
1966 & Saltillo & Cargueiro Ultramar & 3.040 & Brasil \\
1969 & Anahuo II & Cimenteiro Ultramar & 9.834 & Espanha \\
1969 & Azteca & Graneleiro Ultramar & 25.987 & Polônia \\
1969 & Maya & Graneleiro Ultramar & 25.660 & Polônia \\
\hline
\end{tabular}

Fonte: Instituto de Estudios de la Marina Mercante Iberoamericana, 1972

Tabela 4: Aquisições realizadas pela PEMEX em estaleiros no exterior

\begin{tabular}{|c|c|c|c|c|}
\hline Ano & Barco & Tipo & TPB & País de construção \\
\hline 1948 & Salamanca & Tanque Costero & 4.350 & Estados Unidos \\
\hline 1954 & Ignacio Allende & Tanque Ultramar & 17.752 & Alemanha \\
\hline 1955 & Juan Alvarez & Tanque Ultramar & 19.100 & Suécia \\
\hline 1955 & Lázaro Cárdenas & Tanque Ultramar & 16.306 & Grão Bretanha \\
\hline 1956 & Abelardo L. Rodríguez & Tanque Costero & 17.450 & Grão Bretanha \\
\hline 1958 & Guadalupe Victoria & Tanque Ultramar & 19.934 & Holanda \\
\hline 1967 & Cuauhtémoc & Tanque Ultramar & 16.814 & Japão \\
\hline 1967 & José María Morelos & Tanque Ultramar & 20.495 & Japão \\
\hline 1967 & Mariano Escobedo & Gaseiro Ultramar & 9.400 & Grão Bretanha \\
\hline 1967 & Miguel Hidalgo & Tanque Costero & 11.085 & Japão \\
\hline 1967 & Petroquímico I & Gaseiro Ultramar & 2.950 & Grão Bretanha \\
\hline 1967 & Plan de Ayutla & Tanque Ultramar & 20.488 & Japão \\
\hline 1967 & Plan de Guadalupe & Tanque Ultramar & 20.460 & Japão \\
\hline 1967 & Plan de San Luis & Tanque Ultramar & 17.198 & Japão \\
\hline 1967 & Vicente Guerrero & Tanque Ultramar & 8.753 & Japão \\
\hline 1968 & Alvaro Obregón & Tanque Ultramar & 20.463 & Japão \\
\hline 1968 & Benito Juárez & Tanque Ultramar & 20.484 & Japão \\
\hline 1968 & Francisco I. Madero & Tanque Ultramar & 20.500 & Japão \\
\hline 1968 & MelchorOcampo & Tanque Ultramar & 20.495 & Japão \\
\hline 1968 & Plan de Ayala & Tanque Ultramar & 20.397 & Japão \\
\hline 1968 & Plutarco Elias Calles & Tanque Ultramar & 17.198 & Japão \\
\hline 1968 & Venustiano Carranza & Tanque Ultramar & 15.577 & Japão \\
\hline 1970 & Emiliano Zapata & Gaseiro Ultramar & 2.910 & Grão Bretanha \\
\hline
\end{tabular}


O Astilleros Veracruz SA, de propriedade da Nacional Financeira SA e fundado em 1961 a partir da estatização das unidades do dique de San Juan de Ulúa, nasceu com o objetivo de atender grandes encomendas, porém sua capacidade instalada não era suficiente para construir embarcações acima de 1.000 TPB. No entanto, seus diques tinham condições de receber barcos de até 20.000 TPB para apenas fazer reparos. No ano seguinte, em 1962, a partir da estatização do Astilleros Tomas de Rueda (fundado em 1942), foi formado o Astilleros Unidos do Pacifico SA, localizado em Mazatlán, também de propriedade da Nacional Financeira SA. Havia outros estaleiros privados, como a Ingeniria y Maquinaria Especializada SA, com duas unidades produtivas, uma em Salina Cruz e outra em Coatzacoalcos, e o Construcciones Navales de Guaymas SA, uma empresa que operava com a participação de capital espanhol (Instituto para la Integración de América Latina, 1971).

Nessa época ainda estavam em operação pequenos estaleiros no Golfo que construíam embarcações de madeira e ferro para as atividades de pesca e também faziam alguns reparos para a frota mercante nacional. Havia estaleiros em Alvarado, Cidade de Carmem, Campeche e Tampico, onde atuavam junto aos portos pesqueiros. No Pacífico havia estaleiros em Guaymas, Mazatlán, Salina Cruz, Topolobampo e Baja Califórnia. Portanto, o que havia no México eram aglomerações desarticuladas de indústrias da construção naval pesqueira.

Dentro do plano Marcha al Mar, foi estabelecido que se daria prioridade à criação da indústria naval pesada no país. Nesse momento também estavam em vigor o Plano de Metas (1956-1960) no Brasil, que também elegia a indústria naval pesada como uma de suas metas. Para alcançar os objetivos do plano, o estaleiro Veracruz assinou uma cooperação técnica com estaleiros italianos para realizar transferência de tecnologia com o objetivo de fundar as bases da nova indústria naval pesada mexicana. Essa estratégia de constituição de um parque industrial naval estava associada à própria expansão da indústria metal mecânica, à necessidade de renovação da frota da Pemex e à fundação da Transportación Marítima Mexicana e da Compañia Marítima Mexicana. O mesmo ocorreu no Brasil no âmbito do Plano de Metas com a transferência de tecnologia realizada por meio da construção dos estaleiros Ishibras, do Japão, e Verolme, da Holanda, em 1959. Em 1958, o estaleiro Veracruz lançou ao mar os navios México e Zacatecas, ambos com 711 TPB, as primeiras embarcações de "grande" porte construídas no México. Após o término da construção dos dois navios, em 1962, iniciou-se uma série de obras de modernização no estaleiro Veracruz, que por sua vez teve a participação da iniciativa privada por meio de um acordo de transferência de tecnologia assinado com a Maryland Drydock Company, dos Estados Unidos. O estaleiro Unidos del Pacifico fez uma joint venture com o estaleiro holandês Nederlandsche Dock e com um grupo empresarial mexicano Wilton Fijenoord, com o objetivo de construir embarcações de até 10.000 TPB (Secretaria da Marina, 2012; Instituto para la Integración de América Latina, 1971).

Na Tabela 5 podemos acompanhar a trajetória da movimentação portuária da frota mercante mexicana e brasileira. É nítida a diferença do volume de mercadorias movimentadas nos portos brasileiros comparando com os mexicanos. O mesmo ocorre na comparação da frota mercante. Isso expressa a diferença do potencial econômico de cada país. Ambos iniciaram sua trajetória de consolidação econômica com base nas exportações de produtos primários e num mercado interno pouco desenvolvido, e após 1930 deu-se início uma escala contínua de industrialização. O tamanho da população e do território não é determinante para definir o volume do comércio externo, tampouco para definir a dimensão da marinha mercante 
nacional. Reside no seu produto interno, no potencial da indústria e na renda nacional a capacidade que um país tem de impulsionar o mercado externo e compor a sua frota mercante nacional. Como a economia brasileira sempre foi maior que a mexicana, é natural que esses dois indicadores sejam mais favoráveis ao Brasil. Contudo, não explica, nem justifica o atraso que o México teve em fomentar a indústria da construção naval pesada e a marinha mercante.

Tabela 5: Trajetória da movimentação portuária da frota mercante

México e Brasil 1946-1970

\begin{tabular}{|c|c|c|c|c|}
\hline \multirow[b]{2}{*}{ Ano } & \multicolumn{2}{|c|}{ México } & \multicolumn{2}{|c|}{ Brasil } \\
\hline & $\begin{array}{l}\text { Movimentação } \\
\text { portuária (Mil t) }\end{array}$ & Frota mercante (TPB) & $\begin{array}{c}\text { Movimentação portuária } \\
\text { (Mil t) }\end{array}$ & $\begin{array}{l}\text { Frota mercante } \\
\quad(\mathrm{mil} \text { TPB) }\end{array}$ \\
\hline 1946 & 10.057 & 123.423 & 24.879 & 532 \\
\hline 1947 & 11.445 & 103.200 & 30.791 & 856 \\
\hline 1948 & 12.174 & 186.661 & 44.432 & 754 \\
\hline 1949 & 12.899 & 201.259 & 45.204 & 923 \\
\hline 1950 & 14.557 & 222.643 & 46.877 & 569 \\
\hline 1951 & 14.079 & 272.428 & 45.983 & 595 \\
\hline 1952 & 16.336 & 303.766 & 50.596 & 745 \\
\hline 1953 & 16.966 & 308.932 & 53.025 & 895 \\
\hline 1954 & 19.157 & 306.000 & 53.417 & 874 \\
\hline 1955 & 28.004 & 313.000 & 50.677 & 855 \\
\hline 1956 & 19.331 & 319.500 & 51.916 & 879 \\
\hline 1957 & 17.743 & 325.201 & 55.236 & 954 \\
\hline 1958 & 20.212 & 331.877 & 56.605 & 1.026 \\
\hline 1959 & 22.848 & 357.141 & 57.749 & 1.083 \\
\hline 1960 & 26.925 & 370.000 & 59.294 & 1.300 \\
\hline 1961 & 28.730 & 395.032 & 60.985 & 1.308 \\
\hline 1962 & 34.532 & 419.768 & 60.522 & 1.355 \\
\hline 1963 & 34.185 & 478.449 & 59.764 & 1.441 \\
\hline 1964 & 37.753 & 411.219 & 59.620 & 1.424 \\
\hline 1965 & 40.058 & 443.990 & 59.311 & 1.402 \\
\hline 1966 & 41.663 & 498.990 & 62.864 & 1.422 \\
\hline 1967 & 41.614 & 530.694 & 65.605 & 1.431 \\
\hline 1968 & 45.021 & 573.805 & 67.571 & 1.711 \\
\hline 1969 & 45.131 & 620.583 & 72.591 & 1.778 \\
\hline 1970 & 51.641 & 659.439 & 81.878 & 2.339 \\
\hline
\end{tabular}

Fonte: Instituto Brasileiro de Geografia e Estatística, 2010; Instituto Nacional de Estadística y Geografía, 2014.

Nos anos de 1960, as companhias mexicanas de navegação, incluindo a Pemex, seguiram fazendo encomendas em estaleiros no exterior, porém, a exemplo do Brasil, a intenção do governo era que suas encomendas fossem transferidas para os estaleiros nacionais. Com a renovação e ampliação da frota nacional por meio de encomendas no exterior, concomitantemente foi se ampliando a participação da bandeira mexicana na movimentação de longo curso, atingindo portos cada vez mais longínquos. Em 1966, foi lançado ao mar o primeiro cargueiro 
construído no Astilleiros Unidos Pacífico, o El Sargacero, de 589TPB (Secretaria da Marina, 2012). Nessa época, já estavam instalados no Brasil os grandes estaleiros multinacionais (Ishibras e Verolme), e os nacionais (Caneco, Mauá, Só e Emaq) estavam ampliando sua capacidade instalada por meio de incentivos fiscais e financeiros e política de encomendas nacionais. Entre 1959 e 1967, os seis estaleiros entregaram 115 embarcações, num total de 610.295 TPB. O Ishibras tinha capacidade para construir graneleiro de até 25.000 TPB, o Verolme petroleiro de 10.500 TPB e o Mauá graneleiro de 18.100 TPB e petroleiro de 10.500 TPB (Empresa Brasileira de Planejamiento e Transportes, 1999). O Lloyd Brasileiro e a Fronape estavam renovando e ampliando suas frotas por meio de encomendas domésticas (Tabelas 7 e 9). Dada a baixa capacidade dos estaleiros mexicanos, que construíam embarcações de apenas 711 TPB, a Pemex, a TMM e os demais armadores mexicanos eram obrigados a fazer encomendas no exterior.

Tabela 6: Trajetória da Companhia de Navegação Lloyd Brasileiro 1945-1970

\begin{tabular}{cccc}
\hline Ano & Navios & Navios afretados & TPB próprio \\
\hline 1945 & 66 & & 270.000 \\
1950 & 86 & & 373.000 \\
1955 & 70 & & 278.000 \\
1960 & 72 & & 326.000 \\
1961 & 70 & & 233.000 \\
1962 & 53 & & 236.000 \\
1963 & 61 & 12 & 264.000 \\
1964 & 55 & 8 & 264.000 \\
1965 & 60 & 2 & 266.000 \\
1966 & 77 & 22 & 490.000 \\
1967 & 50 & 22 & 480.000 \\
1968 & 50 & 18 & 478.773 \\
1969 & 50 & 22 & 489.335 \\
1970 & 31 & & 280.963 \\
\hline
\end{tabular}

Fonte: Goularti Filho, 2013.

Tabela 7: Aquisições realizadas pela Lloyd Brasileiro em estaleiros nacionais

\begin{tabular}{cccc}
\hline Ano de construção & Nome do navio & TPB & Estaleiro \\
\hline 1962 & Cidade de Belém & 15.794 & Caneco \\
1962 & Cidade de Manaus & 15.795 & Caneco \\
1962 & Henrique Lage & 9.186 & Verolme \\
1962 & Volta Redonda & 5.940 & Ishibras \\
1963 & Almirante Sylvio Motta & 860 & EMAQ \\
1963 & Barão de Jaceguay & 5.993 & Mauá/CCN \\
1963 & Barão do Rio Branco & 5.993 & Mauá/CCN \\
1963 & Londrina & 5.940 & Ishibras \\
1963 & Marília & 5.940 & Ishibras \\
1963 & Pereira Carneiro & 11.319 & Verolme \\
1964 & Barão de Mauá & 6.500 & Mauá/CCN \\
& & Vol. 4 N. 2 - Julio - Diciembre de 2017 & p. 131
\end{tabular}




\begin{tabular}{cccc}
\hline Ano de construção & Nome do navio & TPB & Estaleiro \\
\hline 1964 & Barão do Amazonas & 6.500 & Mauá/CCN \\
1964 & Buarque & 13.160 & Ishibras \\
1964 & Julio Régis & 10.500 & Verolme \\
1965 & Presidente Kennedy & 13.160 & Ishibras \\
1966 & Almirante Graça Aranha & 13.160 & Ishibras \\
1966 & Romeo Braga & 13.160 & Ishibras \\
1970 & Itanagé & 12.490 & Ishibras \\
1970 & Itaquicé & 12.490 & Ishibras \\
\hline
\end{tabular}

Fonte: Goularti Filho, 2013.

Tendo como exemplo a alta capacidade produtiva da indústria naval pesada brasileira, o governo mexicano via como urgente reverter a situação das encomendas dos armadores nacionais. Sobretudo pelas oportunidades geradas pela Pemex, que estava num ritmo acelerado de crescimento, com a descoberta de novas reservas, ampliando sua capacidade instalada e necessitava cada vez de mais de maiores embarcações. Na Tabela 8 podemos acompanhar a evolução da frota de mercante 1950 a 1970. De acordo com a Tabela 2, o volume de produção da Petrobras em 1970 de 59.967 mil de barris, foi atingido pela Pemex em muito acima em 1948. Como é de conhecimento, as reservas mexicanas sempre foram muito superiores às brasileiras. Em compensação, a frota da Petrobras (Fronape) inicia com uma desvantagem em relação à Pemex e chega em 1970 numa posição 3,5 vezes superior à mexicana. Esse crescimento da Fronape pode ser explicado pela capacidade produtiva que os estaleiros brasileiros tinham em atender grandes encomendas, inclusive exportando para o México. A maior renovação da frota da Pemex ocorreu no final dos anos de 1960, quando foram encomendados em estaleiros japoneses dois petroleiros e gaseiros, num total de 202.013 TPB (Tabela 4) (Instituto para la integración de América Latina, 1971; Petrobras, 1970; Pemex, 1977).

Tabela 8: Trajetória da frota da FRONAPE 1950-1970

\begin{tabular}{ccc}
\hline Ano & Navios & TPB \\
\hline 1950 & 4 & 21.940 \\
1951 & 13 & 67.990 \\
1952 & 22 & 224.235 \\
1953 & 22 & 224.235 \\
1954 & 22 & 224.235 \\
1955 & 22 & 224.235 \\
1956 & 25 & 229.950 \\
1957 & 26 & 230.973 \\
1958 & 26 & 230.973 \\
1959 & 31 & 370.004 \\
1960 & 39 & 512.842 \\
1961 & 42 & 542.842 \\
1965 & 41 & 595.702 \\
1966 & 43 & 635.498 \\
1967 & 40 & 608.545 \\
1970 & 32 & 820.000 \\
\hline
\end{tabular}

Fonte: Goularti Filho, 2013. 
Tabela 9: Aquisições realizadas pela Fronape em estaleiros nacionais

\begin{tabular}{cccc}
\hline Ano de construção & Nome do navio & TPB & Estaleiro \\
\hline 1966 & Buracica & 10.927 & Mauá \\
1966 & Carmópolis & 10.671 & Verolme \\
1966 & Jacuípe & 10.788 & Mauá \\
1966 & Quererá & 10.671 & Verolme \\
1967 & Cassarongongo & 10.671 & Verolme \\
1967 & Dom João & 10.788 & Mauá \\
\hline
\end{tabular}

Fonte: Goularti Filho, 2013.

Nos anos de 1950, a prioridade do governo brasileiro era promover a expansão do transporte de longo curso, uma vez que as rodovias estavam integrando o mercado nacional, acelerando o processo de distribuição e circulação das mercadorias. Em 1951, a frota de longo curso era composta por 20 navios e representava apenas 4,0\% do volume das exportações brasileiras (Brasil, 1952). Contando com a navegação interior, havia no País 119 armadores privados, "a maior parte deles empresas de pouca expressão" (Comissão da Marinha Mercante, 1957, p. 6). As grandes bacias hidrográficas estavam reunidas em três áreas, sendo exploradas principalmente pelas autarquias federais: Serviço de Navegação da Amazônia e de Administração do Porto do Pará (SNAPP), criada em 1940 a partir da encampação da The Amazon Steam Navegation; Serviço de Navegação da Bacia do Prata (SNBP), criada em 1943; e, Companhia de Navegação do São Francisco (CNSF), criada em 1955.

No transporte de longo curso atuavam apenas o Lloyd Brasileiro (Tabela 6), a Frota Nacional de Petróleo e a Companhia Siderúrgica Nacional, responsáveis por apenas 3,9\% das exportações e 10,5\% das importações. A cabotagem de longa distância era quase um serviço exclusivo do Estado. Em toneladas por milhas transportadas, 50\% era de responsabilidade de empresas estatais (Comissão da Marinha Mercante, 1957). A estrutura do setor não atendia à demanda do mercado interno, que estava em expansão dado o acelerado processo de industrialização, urbanização e integração do mercado. O Estado brasileiro, que estava assumindo formas superiores de organização capitalista, atendendo às exigências do processo de acumulação, precisava dar uma resposta consistente ao setor de navegação.

Dentro do Plano de Metas, a marinha mercante e a construção naval brasileira, eram complementares, uma vez que não era mais possível pensar na renovação da frota oficial sem o desenvolvimento de uma indústria naval nacional forte e integrada. A partir desse momento, a Comissão da Marinha Mercante deixava de ser apenas um órgão de registro e controle da navegação nacional para se tornar num instrumento de política de incentivos para o setor de navegação e para a indústria da construção naval, gerando expectativas positivas no setor. Como já havia a indústria de aço no País, a expansão e a implantação da indústria da construção naval também seria beneficiada.

Após alguns estudos sobre a marinha mercante, apontando que o seu desenvolvimento estava associado à implantação da indústria da construção naval, e que ambos necessitavam de financiamento, a Lei 3.381, de 24 de abril de 1958, criou a Taxa de Renovação da Marinha 
Mercante (TRMM) e o Fundo da Marinha Mercante (FMM). O FMM era constituído pelos recursos da TRMM arrecadada nas companhias de navegação estrangeiras, oficiais e armadores nacionais que operavam navios estrangeiros fretados. Os recursos seriam recolhidos pelo Banco Nacional de Desenvolvimento Econômico (BNDE) numa conta especial administrada pela CMM. Talvez essa seja a grande diferença institucional e financeira na trajetória dos dois países. O Brasil criou um sistema autônomo de financiamento para fiscal, o TRMM, que formava um fundo de empréstimo para o setor naval, o FMM. No México a Nacional Financeira SA, que era proprietária e sócia de inúmeras empresas, era incapaz de sozinha financiar a indústria mexicana que tinha uma lista enorme de prioridades. Como não houve uma reforma tributária no México, centralizando a capacidade de arrecadação nas mãos da União, nos moldes como ocorreu no Brasil em 1967, as condições de financiamento mexicano eram muito restringidas. Sem crédito, é quase que impossível impulsionar a industrialização pesada.

Nos anos de 1950, havia no Brasil uma pequena indústria da construção naval, com destaque para o estaleiro na Ilha Vianna, que pertencia à Navegação Costeira, especializado em reparos; a Companhia Comércio e Navegação, do Estaleiro Mauá; a Indústria Reunidas Caneco; e o Arsenal da Marinha do Rio de Janeiro, que construía e reparava embarcações da marinha de guerra. Além de vários pequenos estaleiros distribuídos em alguns estados brasileiros. Com a nova política para o setor foram beneficiadas quatro empresas nacionais que já atuavam no mercado (Mauá, Caneco, Só e Emaq). Também foram atraídos grupos estrangeiros, a japonesa Ishikawajima Heavy Industries, que ficou mais conhecida com a Ishibrás, e a holandesa Verolme United Shipyards, ambas em 1959.

Em 1962, com o parque industrial naval quase implantado, e um índice de nacionalização em preço de $81 \%$, encerraram-se as importações de navios novos e de segunda mão (Comissão da Marinha Mercante, 1964; Comissão da Marinha Mercante, 1967). Para os próximos anos, todas as encomendas deveriam ser atendidas pela indústria doméstica, além de começar a exportar, como ocorreu com a primeira encomenda destinada ao México.

\section{Considerações finais}

É possível observar na trajetória da construção naval e da marinha mercante brasileira e mexicana algumas semelhanças e várias diferenças. Como a movimentação portuária brasileira sempre foi maior que a mexicana, criou-se condição para formar uma marinha mercante mais robusta que a mexicana. No Brasil havia mais companhia nacional fazendo o comércio de cabotagem e de longo curso. No México, a cabotagem e o longo curso eram dominados principalmente pelas companhias dos Estados Unidos. A presença do Lloyd Brasileiro foi determinante para formar uma frota nacional mais robusta e com capacidade de atender os portos brasileiros e alguns sul-americanos.

O México tem uma das maiores reservas de petróleo do mundo, e a Pemex sempre esteve entre as maiores petroleiras. Contudo, essa vantagem não foi aproveitada para fomentar a indústria naval nacional até os anos de 1970. No Brasil, assim que foram instalados os grandes estaleiros multinacionais e reaparelhados os nacionais, a Fronape, o Lloyd e outras regionais passaram a renovar suas frotas apenas com aquisições domésticas. No México, os maiores es- 
taleiros, o Veracruz e o Unidos do Pacífico, apesar dos novos investimentos realizados nos anos de 1960, ainda eram incapazes de atender as grandes encomendas da Pemex e a TMM.

Nesse sentido, podemos afirmar que, até os anos de 1970, o Brasil estava num avançado processo de formação de um parque industrial naval e de uma marinha mercante nacional, enquanto o México ainda estava num estágio inicial especializando-se em embarcações pesqueiras. Talvez o elemento diferencial entre as duas economias seja que o Brasil, em 1958, criou o FMM e a TRMM, que permitiam o financiamento a armadores e construtores navais, enquanto o México carecia de um sistema de financiamento próprio para o setor naval.

Outra hipótese que podemos incorrer sobre o baixo grau de desenvolvimento do setor naval mexicano comparado com a brasileiro, é a sua estreita relação comercial com os Estados Unidos. Desde o século xIX, os Estados Unidos sempre foram o maior mercado exportador e importador para o México. No anexo 1 podemos acompanhar a participação dos principais mercados para o México entre 1933 e 1970 e percebe-se que na média deste período os Estados Unidos foram responsáveis por $67,94 \%$ das exportações e $73,0 \%$ das importações. E, basicamente, todo comércio era realizados por companhias de navegação dos Estados Unidos. Dada a proximidade espacial, outra parcela do comércio era realizada por terra (ferrovias e rodovias). Sendo assim, o pujante comércio com o vizinho do norte não era um estímulo ao desenvolvimento da marinha mercante mexicana, mas sim um possível obstáculo. Os estímulos positivos repercutiam na marinha mercante dos Estados Unidos.

\section{Referências}

Ayala Espino, J. (2003). Estado y desarrollo: la formación de la economía mixta mexicana en el siglo xx. Ciudad de México: UNAM.

Brasil. (1949). Mensagem enviada ao Congresso pelo Presidente da República Eurico Gaspar Dutra. Rio de Janeiro: Imprensa Nacional.

Brasil. (1952). Mensagem enviada ao Congresso Nacional pelo Presidente da República Getúlio Vargas. Rio de Janeiro: Imprensa Nacional.

Burlamaqui, A. (1918). A marinha mercante brasileira. Rio de Janeiro: Imprensa Nacional.

Comissão da Marinha Mercante. (1957). Relatórios das atividades da Comissão da Marinha Mercante. Rio de Janeiro.

Comissão da Marinha Mercante. (1964). Relatórios das atividades da Comissão da Marinha Mercante. Rio de Janeiro.

Comissão da Marinha Mercante. (1967). Relatórios das atividades da Comissão da Marinha Mercante. Rio de Janeiro.

Empresa Brasileira de Planejamento de transportes. (1999). Política governamental e competitividade da indústria brasileira de construção naval: evolução, estrutura e diagnóstico. Brasília: Ministério dos Transportes, v. 2.

Escanero Muñoz, F. (1950). Analisis Del dique seco a em San Juan de Uluá. Ciudad de México: Universidad. 
Ferreira Netto, F. (1974). 150 anos de transportes no Brasil 1822-1972. Brasília: Centro de Documentação e Publicação/Ministério dos Transportes.

Goularti Filho, A. (2010). A trajetória da marinha mercante brasileira: administração, regime jurídico e planejamento. Revista Pesquisa \& debate, (21)2, 247-278.

Goularti Filho, A. (2011). História econômica da construção naval no Brasil: formação de aglomerado e performance inovativa. Revista de Economia (ANPEC), (12)2, maio/agosto.

Goularti Filho, A. (2013). Empresas estatais e a consolidação da indústria da construção naval brasileira. Revista de Historia de la Industria, los Servicios y las Empresas en América Lati$n a,(7) 12,38-74$.

Hernández, M. (1965). Consideraciones económicas sobre la construcción naval en México. Ciudad de México: UNAM. (Tese de doutorado - Facultad de Economia).

Instituto Brasileiro de Geografia e Estatística. (2010). Séries históricas. Rio de Janeiro: IBGE.

Instituto de Estudios de la Marina Mercante Iberoamericana. (1972). La marina mercante iberoamericana. Buenos Aires: IEMMI.

Instituto para la Integración de América Latina. (1971). La industria naval en la ALALC. Buenos Aires: BID.

Instituto Nacional de Estadística y Geografía. (2014). Estadísticas históricas de México 2014. Ciudad de México: INEGI.

Jáuregui, L. (2004). Los transportes: siglos XVI al XX. Ciudad de México: UNAM. Kuntz Ficker, S. (2013). La economía mexicana 1519-2010. Ciudad de México, Editora do Colegio de México.

Morales Damián, J. J. (2008). El desarrollo de La marina mercante como actividad prioritária del Estado mexicano. Ciudad de México: UNAM. (Tesis de doctorado - Facultad de Derecho).

Pemex. (1977). Anuario Estadístico. Ciudad de México: Pemex.

Pemex. (1988). Anuario Estadístico. Ciudad de México: Pemex

Petrobras. (1956-1970). Relatórios anuais. Rio de Janeiro. (Série completa).

Rodríguez Ledesma, E. (1977). Evaluación económica de La industria de La construccion naval en México. Ciudad de México: UNAM. (Tesis de doctorado - Facultad de Economía).

Rosales Méndez, E. (2001). Análisis jurídico Del registro público marítimo nacional. Ciudad de México: UNAM. (Tesis de doctorado - Facultad de Derecho).

Secretaría de Comunicaciones y Transportes. (1988). Historia de las comunicaciones y los transportes en México: marina mercante. Ciudad de México: Secretaría de Comunicaciones y Transportes.

Secretaría de Marina (2012). Historia general de La Secretaría de Marina Armada de México: las políticas navales 1940-2012. Ciudad de México: Estado Mayor General.

Solís, M. A. y González Sotomayor, S. (2004). Marina mercante, sistema marítimo portuario como factor y vía de desarrollo económico para México. Ciudad de México: UNAM. (Tesis de doctorado - Facultad de Ciencias Políticas y Sociales). 
Suzigan, W. (2000). Indústria brasileira: origem e desenvolvimento. Campinas; São Paulo: Editora da UNICAMP; HUCITEC.

Tello, C. (2008). Estado y desarrollo económico: México 1920-2006. Ciudad de México: UNAM.

Anexo 1: Exportações e importações mexicanas segundo área geográfica 1933-1970 (em \%)

\begin{tabular}{|c|c|c|c|c|c|c|c|c|c|c|c|c|c|}
\hline \multirow{2}{*}{ Ano } & \multicolumn{2}{|c|}{ EUA } & \multicolumn{2}{|c|}{ Resto da América } & \multicolumn{2}{|c|}{ Europa } & \multicolumn{2}{|c|}{ Asia } & \multicolumn{2}{|c|}{ África } & \multicolumn{2}{|c|}{ Oceanía } & \multirow{2}{*}{$\begin{array}{c}\text { Total (Exp } \\
\text { e Imp) }\end{array}$} \\
\hline & Exp & Imp & Exp & Imp & Exp & Imp & Exp & Imp & Exp & Imp & Exp & $\operatorname{Imp}$ & \\
\hline 1933 & 47,91 & 42,54 & 8,53 & 0,84 & 41,75 & 26,41 & 0,69 & 0,84 & 0,29 & 0,08 & 0,83 & 0,27 & 100,00 \\
\hline 1934 & 51,83 & 60,69 & 7,58 & 1,51 & 38,19 & 35,66 & 1,58 & 1,90 & 0,12 & 0,06 & 0,71 & 0,18 & 100,00 \\
\hline 1935 & 62,80 & 65,33 & 6,00 & 1,30 & 28,27 & 31,29 & 1,97 & 1,72 & 0,17 & 0,13 & 0,79 & 0,23 & 100,00 \\
\hline 1936 & 60,76 & 59,13 & 6,67 & 1,69 & 29,14 & 36,07 & 2,62 & 2,68 & 0,16 & 0,06 & 0,65 & 0,37 & 100,00 \\
\hline 1937 & 56,23 & 62,15 & 7,51 & 2,98 & 33,88 & 32,12 & 1,39 & 2,05 & 0,19 & 0,13 & 0,80 & 0,56 & 100,00 \\
\hline 1938 & 67,39 & 57,66 & 2,33 & 3,53 & 29,59 & 37,83 & 0,58 & 0,22 & 0,00 & 0,14 & 0,20 & 0,60 & 100,00 \\
\hline 1939 & 74,24 & 66,04 & 1,43 & 2,07 & 23,04 & 28,92 & 1,19 & 2,16 & 0,02 & 0,35 & 0,08 & 0,46 & 100,00 \\
\hline 1940 & 89,45 & 78,82 & 1,86 & 3,73 & 5,48 & 13,66 & 3,06 & 3,01 & 0,05 & 0,24 & 0,09 & 0,54 & 100,00 \\
\hline 1941 & 91,19 & 84,28 & 5,23 & 4,38 & 0,57 & 7,43 & 2,96 & 3,24 & 0,01 & 0,06 & 0,04 & 0,62 & 100,00 \\
\hline 1942 & 91,40 & 87,24 & 8,50 & 6,66 & 0,09 & 5,43 & 0,00 & 0,23 & & 0,03 & 0,01 & 0,41 & 100,00 \\
\hline 1943 & 86,99 & 88,55 & 12,10 & 7,03 & 0,30 & 4,03 & 0,00 & 0,00 & 0,55 & 0,07 & 0,06 & 0,31 & 100,00 \\
\hline 1944 & 85,05 & 88,07 & 13,29 & 6,97 & 0,51 & 2,12 & 0,01 & 0,00 & 1,03 & 0,01 & 0,10 & 1,23 & 100,00 \\
\hline 1945 & 83,50 & 82,37 & 15,69 & 11,08 & 0,57 & 4,93 & 0,05 & 0,02 & 0,20 & 0,06 & 0,00 & 1,54 & 100,00 \\
\hline 1946 & 70,01 & 83,60 & 16,00 & 9,11 & 3,50 & 6,56 & 8,13 & 0,05 & 0,52 & 0,09 & 0,00 & 0,59 & 100,00 \\
\hline 1947 & 76,57 & 88,42 & 9,49 & 2,99 & 7,38 & 7,73 & 6,13 & 0,43 & 0,35 & 0,02 & 0,07 & 0,40 & 100,00 \\
\hline 1948 & 75,34 & 86,75 & 8,18 & 3,03 & 13,89 & 9,21 & 1,84 & 0,77 & 0,72 & 0,02 & 0,02 & 0,24 & 100,00 \\
\hline 1950 & 86,35 & 84,40 & 6,29 & 3,18 & 5,47 & 10,41 & 1,68 & 1,00 & 0,19 & 0,06 & 0,02 & 0,95 & 100,00 \\
\hline 1951 & 70,44 & 81,50 & 6,75 & 2,56 & 16,54 & 12,90 & 5,89 & 2,10 & 0,37 & 0,09 & 0,01 & 0,84 & 100,00 \\
\hline 1952 & 78,57 & 82,77 & 5,26 & 3,02 & 9,36 & 12,83 & 6,51 & 0,69 & 0,29 & 0,07 & 0,01 & 0,61 & 100,00 \\
\hline 1953 & 72,26 & 77,11 & 8,01 & 8,35 & 11,18 & 13,27 & 8,51 & 0,67 & 0,03 & 0,08 & 0,00 & 0,53 & 100,00 \\
\hline 1954 & 60,06 & 80,47 & 22,58 & 3,18 & 11,94 & 13,85 & 5,37 & 1,05 & 0,04 & 0,16 & 0,00 & 1,28 & 100,00 \\
\hline 1955 & 60,66 & 79,33 & 22,89 & 3,76 & 11,27 & 14,50 & 4,87 & 1,05 & 0,12 & 0,09 & 0,20 & 1,27 & 100,00 \\
\hline 1956 & 56,09 & 78,32 & 26,89 & 4,26 & 11,78 & 15,52 & 4,93 & 1,00 & 0,16 & 0,05 & 0,15 & 0,86 & 100,00 \\
\hline 1957 & 64,35 & 77,02 & 21,49 & 4,19 & 10,47 & 16,54 & 3,20 & 0,96 & 0,15 & 0,36 & 0,35 & 0,93 & 100,00 \\
\hline 1958 & 61,04 & 76,99 & 25,63 & 3,12 & 8,89 & 17,52 & 3,14 & 1,51 & 0,23 & 0,12 & 1,07 & 0,74 & 100,00 \\
\hline 1959 & 60,72 & 72,91 & 21,62 & 3,95 & 9,19 & 20,28 & 7,95 & 1,82 & 0,24 & 0,13 & 0,29 & 0,90 & 100,00 \\
\hline 1960 & 61,49 & 72,07 & 19,06 & 4,14 & 11,55 & 20,93 & 7,19 & 1,97 & 0,35 & 0,10 & 0,36 & 0,79 & 100,00 \\
\hline 1961 & 62,39 & 69,83 & 19,45 & 4,37 & 8,73 & 22,68 & 8,51 & 2,22 & 0,33 & 0,08 & 0,58 & 0,82 & 100,00 \\
\hline 1962 & 61,42 & 68,24 & 19,37 & 4,87 & 8,94 & 23,73 & 9,41 & 2,16 & 0,53 & 0,06 & 0,33 & 0,94 & 100,00 \\
\hline 1963 & 63,69 & 68,50 & 18,15 & 5,45 & 8,98 & 21,90 & 8,50 & 2,71 & 0,29 & 0,57 & 0,39 & 0,88 & 100,00 \\
\hline 1964 & 59,54 & 68,48 & 19,91 & 6,31 & 11,03 & 21,35 & 8,94 & 2,39 & 0,36 & 0,04 & 0,23 & 1,44 & 100,00 \\
\hline 1965 & 56,19 & 65,71 & 18,80 & 5,09 & 13,61 & 24,76 & 8,95 & 3,09 & 2,10 & 0,02 & 0,35 & 1,32 & 100,00 \\
\hline 1966 & 54,33 & 63,80 & 23,27 & 5,67 & 12,05 & 25,92 & 9,63 & 3,54 & 0,31 & 0,04 & 0,40 & 1,03 & 100,00 \\
\hline 1967 & 56,12 & 62,88 & 20,57 & 5,28 & 14,93 & 25,74 & 7,63 & 4,93 & 0,19 & 0,04 & 0,56 & 1,13 & 100,00 \\
\hline
\end{tabular}


138 Marinha mercante e construção naval mexicana e brasileira: a comparação de uma trajetória histórico-econômica, doi: http://dx.doi.org/10.21789/24222704.1224

\begin{tabular}{|c|c|c|c|c|c|c|c|c|c|c|c|c|c|}
\hline \multirow{2}{*}{ Ano } & \multicolumn{2}{|c|}{ EUA } & \multicolumn{2}{|c|}{ Resto da América } & \multicolumn{2}{|c|}{ Europa } & \multicolumn{2}{|c|}{ Asia } & \multicolumn{2}{|c|}{ África } & \multicolumn{2}{|c|}{ Oceanía } & \multirow{2}{*}{$\begin{array}{c}\text { Total (Exp } \\
\text { e Imp) }\end{array}$} \\
\hline & Exp & $\operatorname{Imp}$ & Exp & Imp & Exp & Imp & Exp & Imp & Exp & Imp & Exp & Imp & \\
\hline 1969 & 66,58 & 62,42 & 11,93 & 5,39 & 12,55 & 25,84 & 8,59 & 5,35 & 0,08 & 0,08 & 0,28 & 0,92 & 100,00 \\
\hline 1970 & 70,90 & 63,62 & 12,22 & 5,76 & 10,02 & 25,72 & 6,51 & 4,26 & 0,10 & 0,10 & 0,25 & 0,54 & 100,00 \\
\hline $\begin{array}{l}\text { Mé- } \\
\text { dia }\end{array}$ & 67,94 & 73,00 & 13,58 & 4,47 & 13,12 & 18,99 & 4,72 & 1,85 & 0,31 & 0,11 & 0,28 & 0,76 & 100,00 \\
\hline
\end{tabular}

Fonte: Instituto nacional de estadística y geografía. (2014).

Estadísticas históricas de México 2014. Ciudad de México: INEGI. 